"Results of Recent Magnetic Observations in Mexico (1906-8)," by Felipe Valle; "The Magnetic Storms of September, 1908," by O. H. Tittmann; "Letters to Editor," "Notes," etc.

\section{THE NEWEST ANCIENT MAN}

Yesterday (December 14) before the Academy of Sciences Professor Edmond Perrier, director of the Museum d'Histoire Naturelle exhibited a skull to which he ascribes a great importance. The skull, together with other parts of the skeleton (bones of the upper and lower limbs), was found about six months ago by two abbés (Bouyssonie and Bardon) in some excavations being made near Chapelleaux-Saints in the Corrèze.

The rock strata in which these bones were found are, according to M. Perrier, of middle Pleistocene age.

The skull is that of a man of extremely low type, an ape-man, or perhaps of a man-ape of greater cranial capacity than any at present known. This great cerebral development leads M. Perrier to consider it, on the whole, a human skull. But the very thick, low cranial dome, the flattened forehead and pronounced orbital ridges, the broad nose separated from the forehead by a deep furrow, and the much elongated snout-like maxillaries combine to give the skull a marked gorilla-like seeming. The brain cavity, however, is as already said, very much larger than that of the gorilla or any other present-day anthropoid.

The limb bones are curved and present a conformation which indicates that this Pleistocene man walked more often on all-fours than in an erect position. The bones seem to be fairly intermediate between those of a man and those of the present-day anthropoids.

Altogether Professor Perrier (whose scientific standing gives his opinions in the matter high authority) believes that he has in his hands-the specimens have been purchased by the museum-remains much more ancient than those of Neanderthal or Spy, and actually representing a type intermediate between Pithecanthropus and present man.
Those interested should watch for the more detailed and authoritative report of Professor Perrier's account which will appear in the Comptes Rendus.

PARIS, Vernon L. KellogG

December 15

\section{THE INDIANA UNIVERSITY EXPEDITION} TO BRITISH GUIANA

Professor Carl Eigenmann, dean of the Graduate School of Indiana University, has just returned from a four months' trip to British Guiana, where he was engaged in the study and collection of South American fishes. He was accompanied by S. E. Shideler as a volunteer assistant. Professor Eigenmann is now engaged in a monograph of the freshwater fishes of tropical America. The trip to British Guiana had three objects. It was intended to collect as many species of freshwater fishes as possible from one of the South American rivers flowing north; to photograph living fishes, and to collect on the plateau of Guiana.

Fishes were collected near the mouths of rivers from the Berbice River on the east to Morawhana near the Orinoco on the west. In the Demarara River collections were made at Georgetown, at Nismar, near the head of tide water, about sixty miles from the coast, and at Malali, almost thirty miles further up stream at the first rapids.

In the Essequibo River collections were made at Bartica, Rockstone, Crab Falls and the Warraputa Cataract.

For an attack on the Guiana Plateau the Potaro River was selected. It is a tributary of the Essequibo about ninety miles from the coast. There are a series of short cataracts with long stretches of navigable water in between. The first of the rapids are at Tumatumari where extensive collections were made. From the next rapids, near Potaro Landing a path of seven miles brings one above the Ichaura, Aurituk, Cöbanatuk and Pakatuk Cataracts to Cangaruma. From here on the trip was continued with the boats and crew of sixteen Indians, generously put at the service of the expedition by Messrs. G. Iinnel and 